Anales de Literatura Hispanoamericana

ISSN: 0210-4547

\title{
Rubén Darío y Santiago Rusiñol: otro ejemplo de la pintura como escritura
}

José Carlos Rovira ${ }^{1}$

Resumen. La relación de la pintura y la poesía es de nuevo el argumento de este trabajo sobre Darío que se inicia con su formación en Chile en 1886 a través del joven Pedro Balmaceda, e indica su persistente penetración en la pintura europea y española a partir de su segundo viaje a España en 1899. Algunos encuentros con la pintura-paisaje-poesía abren su atracción por la obra de Santiago Rusiñol, a la que se acerca desde su llegada a España y a la que continúa prestando atención siempre, siendo Jardins d'Espanya (1902), del escritor y pintor catalán, el objeto de apreciaciones y valoraciones concretas que son relevantes para la escritura de quien sin duda, acorde con el modernismo que había definido en la tradición hispanoamericana, convirtió su producción poética y prosística en un conjunto de imágenes vinculado a la pintura y a modelos de la misma.

Palabras clave: pintura; poesía; écfrasis; paisajes; Santiago Rusiñol; Jardins de Espanya.

\section{[en] Rubén Darío and Santiago Rusiñol: another exemple of painting as a writing}

\begin{abstract}
The bond between painting and poetry is, once again, the main topic of this paper about Rubén Darío. It follows Darío's educational stage with young Pedro Balmaceda in Chile during the year of 1886, and depicts his persistent insight into European and Spanish painting since his second travel to Spain in 1899. The blend of painting, landscape and poetry drove his attentionto the work of Catalonian writer and painter Santiago Rusiñol, in which he would remain interested ever since. Particularly, Rusiñol's Jardins d'España (1902) gave rise to many remarks and appreciations, undoubtedly relevant to his later writing. Thus,Darío turned his prose and poetry in an ensemble of images closely related to painting and its models, in accordance to the modernist movement he had earlier established in Hispanic-American tradition.
\end{abstract}

Keywords: painting; poetry; ekphrasis; landscape; Santiago Rusiñol; Jardins d'Espanya.

Sumario. 1. Encuentro con el poema-pintura. 2. Para la creación de paisajes.

Como citar: Rovira, J.C. (2017) Rubén Darío y Santiago Rusiñol: otro ejemplo de la pintura como escritura, en Anales de Literatura Hispanoamericana 46, 117-130.

1 Universidad de Alicante.

E-mail: rovi@ua.es 
Es muy frecuente la referencia pictórica en la obra del poeta Rubén Darío y hay una amplia tradición crítica sobre ello. Un artículo reciente del maestro Ivan Schulman, titulado "Darío: pintor" (Schulman, 2014: 23-32), situó en el ámbito general del modernismo la nueva construcción de la écfrasis que se asume y se recupera, aquella relación que Darío sintetiza en una sencilla frase: "Hay mucho de pintura en la poesía, y hay mucho de poesía en la pintura" (Darío, 1950: I, 661). Destaca Schulman el papel que un marchante y editor como Adolphe Goupil, con su Tesoro de las Bellas Artes modernas tuvo por sus brillantes reproducciones para el mundo cultural hispanoamericano y europeo. A éste dedica Darío su "Goupil, el Tesoro de Bellas Artes modernas" (Darío, 1920 circa: 17-36) destacando que aquellas reproducciones de calidad permitían hacerse una idea de los cuadros contemporáneos, sin tener que ir a museos que quedaban muy lejos.

Recientemente he destacado también el primer tiempo formativo de Darío en la pintura, y fue éste sin duda el que se inicia en 1866 en Chile y dura dos años y ocho meses: grabados con imágenes de Wateau o Poussin, o la amplia colección de revistas francesas y de cuadros de pintores chilenos que Pedro Balmaceda Toro hijo del Presidente de la República- tenía en el Palacio de la Moneda, frecuentada por el poeta, junto a su formación en la crítica de arte de Balmaceda, narrada por Darío en el volumen que le dedicó en su temprana muerte, es la fuente formativa de Darío y el origen de la transposición pintura-poesía que aparece en las prosas de $A z u l$ y en la actitud de Ricardo, el poeta del "Álbun porteño" que recorre los cerros de Valparaíso "en busca de cuadros"(Rovira, 2016a : 22-25).

No hay duda también, y a eso he dedicado otro trabajo reciente, de la relación que construye Darío entre los paisajes pictóricos y los literarios, haciendo de la frecuente crítica de exposiciones en Francia, España e Italia, no sólo un recurso de supervivencia, pues eran crónicas periodísticas (para La nación de Buenos Aires principalmente), sino sobre todo una búsqueda incesante de pinturas-poemas que, descritos a través de prosas que demuestran sabiduría crítica, podía convertir luego en poemas propios o en brillantes descripciones narrativo-pictóricas (Rovira, 2016b: 131-157)

Hay sin duda un Darío que tuvo la pintura como elemento de creación y sus poemas dedicados o con referencias a Jean-AntoineWatteau, Nicolas Poussin, Gustave Moreau, Aubrey Beardsley ${ }^{2}$, la pintura prerrafaelita, o el movimiento art nouveau ; o en otra tradición más clásica, Leonardo da Vinci, Velázquez, Goya... ${ }^{3}$. Hay también una referencia esencial a los contemporáneos, franceses y españoles, y la he recorrido en "Rubén Darío: geografía, pintura y paisajes" (Rovira, 2016b: 131-157), donde llamaba la atención sobre varios pintores, como Nicolás Raurich i Petre, en el que Darío encontraba el poema-paisaje, o la desconcertante posición sobre Joaquín Sorolla del que reconocía "su vasto dominio de la pintura y su indigente comprensión del arte"

2 Me sigue pareciendo importante, entre tantos otros trabajos posteriores, el artículo de Carlos MARTÍNEZ RIVAS (1967: 445-452). También Lily LITVAK, 1988: 51-66. Desde una perspectiva teórica es importante además el trabajo de la misma autora, Lily LITVAK, 1988b: 133-154.

3 En Rubén DARÍO, 2004. $Y$ en el amplio comentario final de esta edición, hay varias indicaciones para los poemas VI: "Salutación a Leonardo", y de "Otros poemas", VII: "Trébol”, y XXVIII: "A Goya".

4 Sobre la visión de Sorolla, globalizando el concepto de modernidad, es importante el trabajo de Alberto ACEREDA, 2003: 119-143. 
En ese trabajo, abandoné por cuestiones de espacio editorial el tratamiento de una figura que el poeta nicaragüense consideró muy importante para la relación poesía-pintura, como fue el catalán y modernista por excelencia Santiago Rusiñol ${ }^{5}$, con el que mantuvo una importante relación que planteo ahora.

Llegamos a Santiago Rusiñol, a través de Darío, gracias a dos versos de la "Epístola a la señora de Lugones", ese ejemplo principal de coloquialismo y memoria cultural y personal:

\section{En Pollensa ha pintado Santiago Rusiñol} cosas de flor de luz y de seda de sol. (Darío, 2011: 539)

Encontramos también a Rusiñol en aquellos versos, un poco peores, que están plasmados en una placa en la casa del Paseo de Gracia, número 96, en la que vivió un tiempo el artista catalán:

¡Gloria al buen catalán que hizo a la luz sumisa

jardinero de ideas, jardinero de sol

y al pincel y a la pluma y a la barba y a la risa

con que nos hace alegre la vida Rusiñol!

Los leyó Darío en el homenaje ciudadano al pintor desarrollado en Barcelona en 1914, homenaje en el que el poeta se presentó de improviso.

La historia de la relación con Santiago Rusiñol es larga sin embargo y creo que muy significativa en términos de lo que planteamos de la relación paisaje-pintura. Es en el tiempo de España contemporánea, al poco de llegar Darío en su segundo viaje a España, cuando conoce a Rusiñol en Barcelona. La primera crónica de tierra firme, la titulada "Barcelona", tiene la fecha del 1 de enero de 1899. Se ha destacado en ella el dinamismo social que Darío ve en esta ciudad y en Cataluña, frente a sus visiones desoladas, las de la España "del desastre" de la que va a hacer crónica encargada por La Nación de Buenos Aires. Como ha estado muy poco tiempo en la ciudad, tras describir positivamente elementos de la sociedad que ve, anuncia que volverá pronto:

He de volver a Cataluña, donde no he estado sino rápidamente, $\mathrm{y}$ he de estudiar esa existencia fabril que se desarrolla prodigiosa en focos como Reus, Mataró, Villanueva, y entre otros tantos, Sitges, donde tiene su morada el singular y grande artista que se llama Santiago Rusiñol. (Darío, 1917: 14)

Rusiñol es presentado ampliamente a continuación, primero como símbolo del movimiento intelectual que sigue "al movimiento político y social": el universal pensamiento moderno que Darío ha bautizado como modernismo, según planteó por primera vez en 1988:

Existe un trabajo importante sobre la relación de Darío con Rusiñol, pero no trata la reflexión que realiza el poeta sobre la pintura de éste y se centra en el contexto social e histórico de la Barcelona modernista y el nacionalismo catalán de comienzos de siglo: cf. Martí Monterde, 2016: 275-304. 
El nombre de Rusiñol me conduce de modo necesario a hablaros del movimiento intelectual que ha seguido, paralelamente, al movimiento político y social. Esa evolución que se ha manifestado en el mundo en estos últimos años y que constituye lo que se dice propiamente el pensamiento $<<$ moderno $>>$ o nuevo, ha tenido aquí su aparición y su triunfo, más que en ningún otro punto de la Península, más que en Madrid mismo; y aunque se tache a los promotores de ese movimiento de industrialistas, catalanistas, o egoístas, es el caso que ellos, permaneciendo catalanes, son universales. (Ibidem, 14-15)

El "modernisme" catalán, como estilo arquitectónico de final de siglo, avanzaba hacia las corrientes principales pictóricas, hacia la tipografía, que ya es europea por su calidad nos relata Darío. Dirige una vez sus pasos al café artístico "Els quatre Gats", donde pregunta por Rusiñol, pero su dueño, Pere Romeu, le dice que está en Sitges, aunque le muestra el local (un "remedo" del parisino "Le Chat Noir", nos compara), donde ve un espectáculo de marionetas, y los cuadros de pintores que pueblan las paredes, entre los que está el que buscaba, del que nos afirma: "Un Rusíñol es floración que significa el triunfo de la vida moderna y la promesa del futuro...". Se va ahora a un Madrid que sabe que va a ser diferente.

\section{Encuentro con el poema-pintura}

En Parisiana (1905), entre anécdotas de la realeza exiliada en Francia, jardines, reflejos de la ciudad pobre y su infancia, cementerios para animales que le enfadan por la gente que mientras vive en pobreza, referencias culturales y muestras pictóricas, tenemos un nuevo ejemplo de su pasión por este país y su capital. "Impresiones de 'Salón'"es una nueva reflexión por la pintura y en ella destacan autores franceses muy conocidos, hasta llegar a una apreciación sobre Rusiñol que expone junto a otros españoles

En donde se quedan por largo rato los artistas, los conocedores de lo bello discreto, de lo bello amable, de lo bello ensoñador, los adoradores de la poesía pintada, es ante los cuadros de Santiago Rusiñol. Poesía de los «jardines de España», poesía de los arrayanes y de los cipreses; poesía de los solitarios y viejos y melancólicos rincones llenos de la nobleza desvanecida de antiguas edades; poesía de los almendros en flor en el campo verde cerca del mar azul, en las luminosas Baleares; patio de los naranjos, con las notas de oro, en el obscuro ramaje; blancas barcas; melancolía del valle en la ternura de la tarde, y la maravilla solar anotada en pautas delicadas. Baste decir que en las telas de este poeta, hay el mismo charme profundo y aristocrático que en sus prosas poémicas. (Darío, 1917b: 185).

Sin duda "Almendros en flor en Mallorca" es el cuadro que está contenido en la referencia "poesía de los almendros en flor en el campo verde cerca del mar azul, en las luminosas Baleares": 


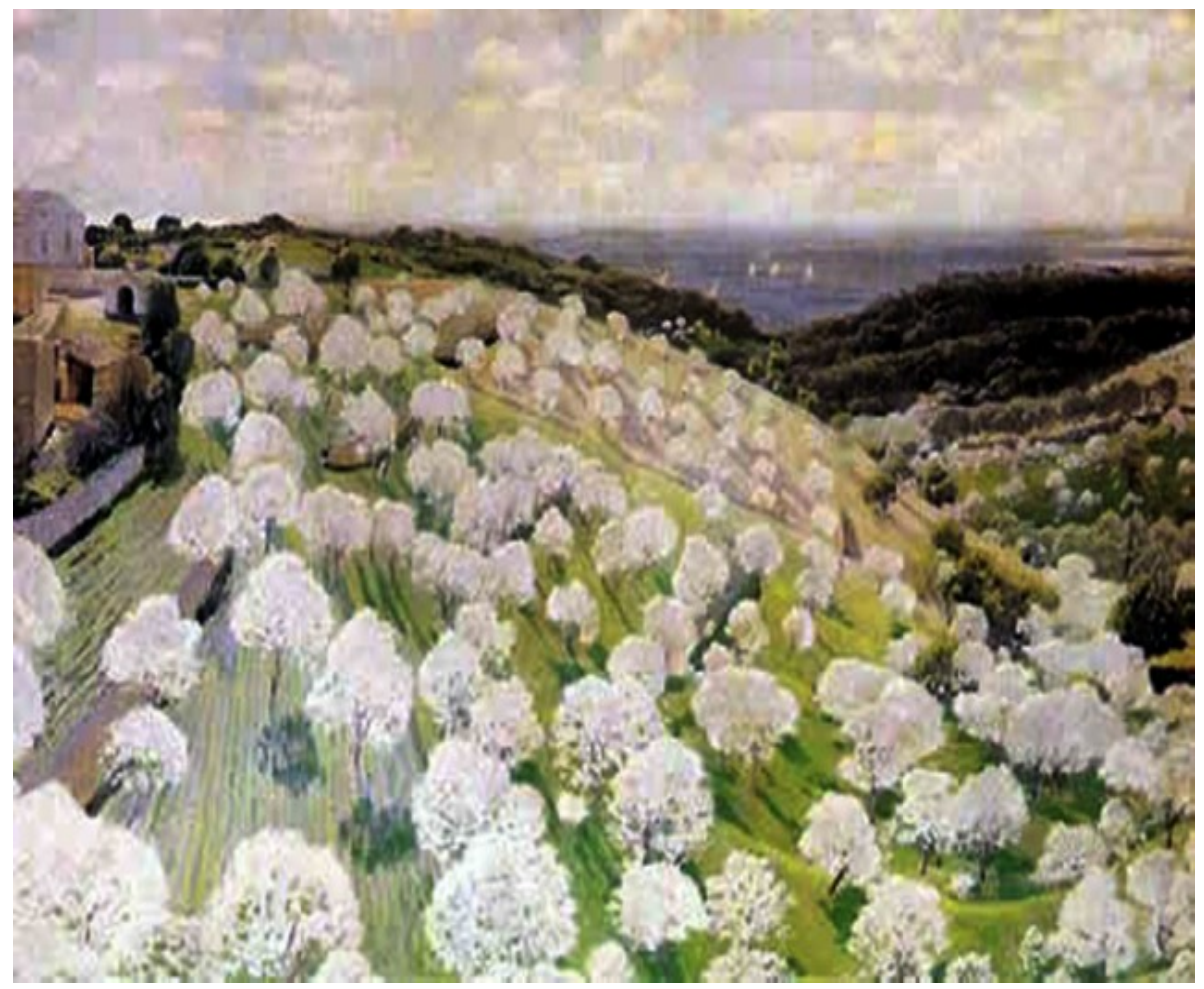

Almendros en flor en Mallorca

Pintado en 1902, perteneciente en la actualidad al Museo de Bellas Artes de la Habana, es un modelo de simetría floral que anuncia la primavera mallorquina que Darío sitúa en un conjunto de referencias a la pintura de Rusiñol, que va a ser muy abundante como veremos a continuación.

La referencia "Poesía de los «jardines de España», poesía de los arrayanes y de los cipreses; poesía de los solitarios y viejos y melancólicos rincones llenos de la nobleza desvanecida de antiguas edades" nos pone delante unos cuadros, y el libro que los contenía, que fue auténticamente una atracción para Darío: "Jardins d'Espanya", publicado también en castellano, y aparecido en 1903, en Can Thomas de Barcelona (una famosa editorial de libros de arte) donde el pintor recorre en cuarenta láminas sus jardines de Granada y Mallorca, pero también de Aranjuez (que será en otras ocasiones escenario principal), Tarragona, Montserrat, Valencia, La Granja (Segovia), Barcelona y Sitges. Con el título de Primaveral aparece el grabado procedente del cuadro "Almendros en flor en Mallorca": 


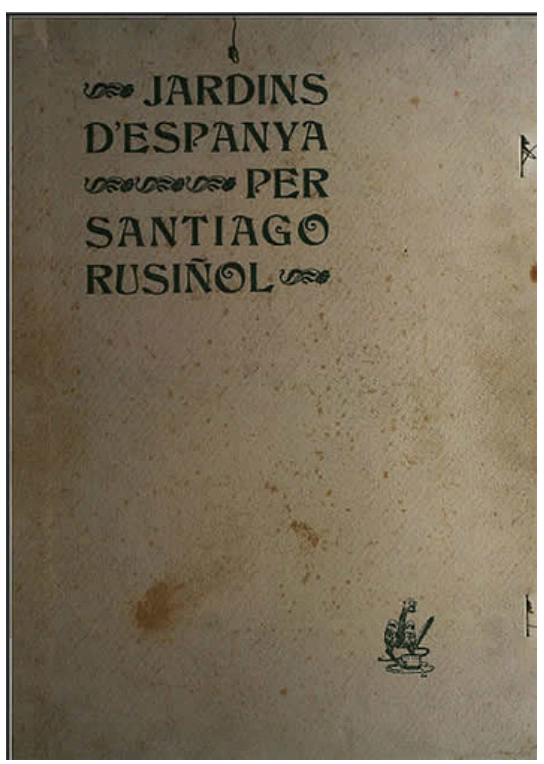

El libro es importante también porque, como prólogo a unas imágenes que tienen excelente reproducción, aparece un texto del mismo Rusiñol -también gran narrador y dramaturgo -y un conjunto de poemas en catalán que firman M.S.Oliver, Joan Alcover, Apeles Mestres, Miquel Costa y Llobera, E. Guanyabéns, F. Matheu, Joan Maragall y Gabriel Alomar con un extenso "Floralia" que concluye el conjunto unificado por el tema de los jardines, en un desarrollo concreto muchas veces sobre las imágenes con las que podemos ejemplificar la écfrasis modernista.

El prólogo de Rusiñol es una reflexión amplia sobre los jardines del presente, los que ha recorrido y pintado "abans no acabin de borrar-se" (Rusiñol, 1903: 1); es una reflexión entre "Renaixença" y Regeneracionismo ("Ja posta, aquesta tarde d'estiu, com que les flors duren menos que les plantes, abans que Espanya estés malalta van anar morint-se'ls jardins" (Ibídem: 2), en los que la metáfora de las flores ocupa un espacio principal para trazar la decadencia de un país en el que en el pasado los jardines de La Granja y Aranjuez, los plantados en la época "dels Carles y dels Felips" fueron recogidos por Velázquez. Y sin embargo "Morien els vells jardins, però morien am tanta noblesa, que de la mort en brotava una nova poesia: la poesia de les grandeses caigudes" (Ib: 3). El tópico de los jardines abandonados, tan frecuente en las reflexión literaria inmediata y posterior, lo crea en su época sin duda Rusiñol ${ }^{6}$.

La reflexión social se aúna sin embargo a la artística, a la relación pinturapoesía:

Els jardins són el paisatge posat en vers, i els vers escrits en plantes van escassejant pertot arreu; és que els jardins són versos vius, versos amb saba i amb aroma, i com el jardiner poeta, per a rimar el llargs caminals ombrivols, per a estilizar els boixos fent-los seguir simetriques harmonies, per a posar en

6 Cf. El interesante análisis de José María Balcells , 199: 33-58. 
estrofes de verdor les imatges de les plantes i les teories de figures, per a versificar la Natura i fer cants d'ombres i clarors...(Ib.: 1),

para hacer finalmente una llamada a los poetas:

Vés-hi aviat, que enlloc podras somniar a més bona ombra; vés-hi, si vols encomanar-te un moment aquella tristesa somniosa que't fa aclucar el pensament pera poder somniar més estona; que't dóna desig de fer versos i barrar-los com se barren els versos fets de jardins; que't dóna desitjos d'abraçar les formes que's desvaneixen, i les figures que cauen, i les grandeses que moren. Vés-hi, poeta, si vols escoltar la poesia, un bon moment de la vida. (Ib.: 3).

En 1903 apareció también la edición en castellano en la misma casa editorial y Azorín acompañaba a Rusiñol con un prólogo, mientras aparecían en el libro poemas castellanos de Manuel Machado, Eduardo Marquina, Ramón Pérez de Ayala, Juan Ramón Jiménez y se mantiene el poema de Jo an Maragall. Sobre el impacto de este libro en la cultura española, es imprescindible oír, en cualquier momento del día y los días, las Noches en los Jardines de España (1909-1916) del maestro Manuel de Falla que probablemente compuso en la estela cultural del libro de Rusiñol, aunque haya un debate crítico sobre ello, en el que lo único innegable es que las terminó en el piano de Rusiñol en su casa de Sitges.

Darío recorrió a Rusiñol como imagen pictórica y personal, comentando algunos de sus jardines en un artículo que con el nombre del pintor apareció en $L a$ Nación de Buenos Aires el 7 de abril de 1907, convirtiéndose luego en el capítulo segundo de su inacabada La isla de oro ${ }^{7}$. Resulta importante recordar las imágenes que selecciona y analiza, aunque es previo recordar la imagen del pintor en Mallorca que construye. Dice el poeta:

Rusiñol encendió su pipa; y así pudo verse, a través de un velo de sutil humo, su hermosa testa de artista; el mechón gris sobre el marfil de la frente, la mirada llena de la fatiga del ensueño, la sonrisa de buen muchacho. Hacía tiempo que la inglesa era admiradora de las prosas y de los cuadros de ese catalán de seda. Uno de esos cuadros nos fue evocado por los almendros floridos. Era una tela expuesta en el Salón de París, hace pocos años. (Darío, 1978: 29)

Tras el recuerdo del cuadro que conoció en París en 1905, comenta a continuación Darío algunos grabados de los que están en el libro y doy nota aquí de algunas de las afirmaciones que va haciendo, junto a las imágenes a las que se refiere.

Inicia con "Darrer jardí", con el que el espacio solitario se convierte en interior, en sensación de soledad con la puerta que atrae una figura inexistente, pero posible

Llegué a estas referencias sin duda por un artículo de Fabián Montojo titulado "Rubén Darío. La isla de oro. Jardines de España", en su Web En alta mar (http://fabian.balearweb.net/post/116200) consultado en marzo (día 16 y varias veces más) de 2016. Fallecido su autor el 28 de diciembre de 2015, hoy sólo puedo agradecer con la memoria su trabajo, que era básicamente sobre la isla que le apasionaba, pero que también abrió muchas referencias culturales sobre la misma. 
en estado de meditación a través del camino que entrelaza la doble hilera de cipreses y la entrada en el fondo seguramente a un cementerio:

Yo amo los jardines de España que han hecho peregrinar al artista, satisfaciéndole en cambio con el don de sus almas melancólicas, sílvicas o aristocráticas. Amo este «Darrer jardí» mallorquín en el cual entre flores y árboles espesos y oscuros no hay más que una soledad en espera de inminente presencia que vaya con paso de meditación hacia la solitaria puerta que se abre en la claridad del fondo. (Ibídem)

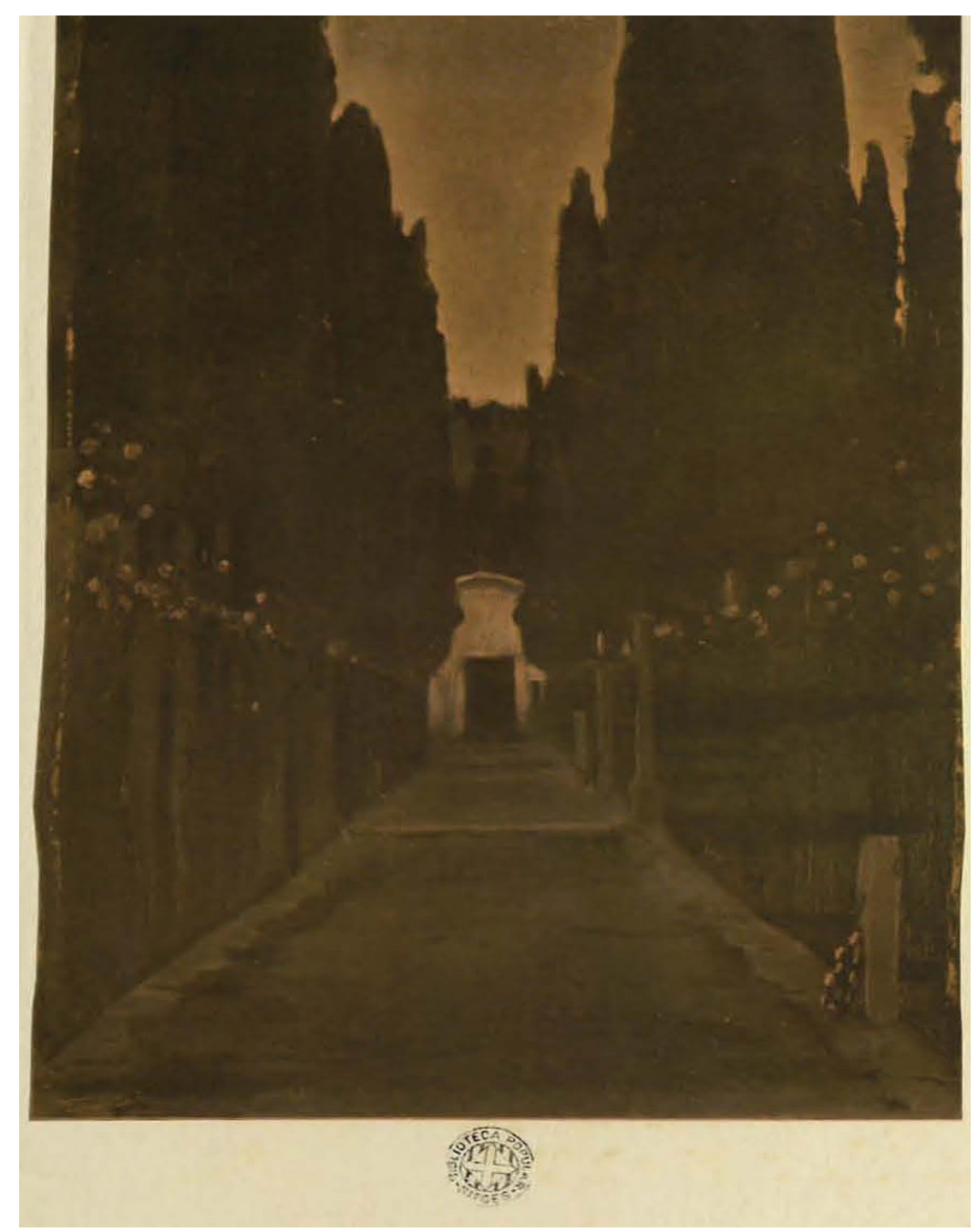

Darrer jardí 
Uno de los pocos grabados coloreados de la colección, la Fuente de la Odalisca, nos remite a la simetría de los troncos enlazados y al recuerdo seguro de aquella Granada de las odaliscas que tanto amó la pintura contemporánea (hasta la exaltación esencial que realizará luego el maestro Henrri Matisse). La referencia daríana a Las mil y una noches es parte del reconocimiento orientalista del poeta en los espacios que ve:

Me deleita la "Fuente de la Odalisca", en la mágica Granada, donde en un escenario miliunanochesco se abren las rosas rojas junto a los macizos de arrayanes, y el agua se vierte en la taza antigua bajo las simetrías entrelazadas de los educados troncos. (Ibídem)

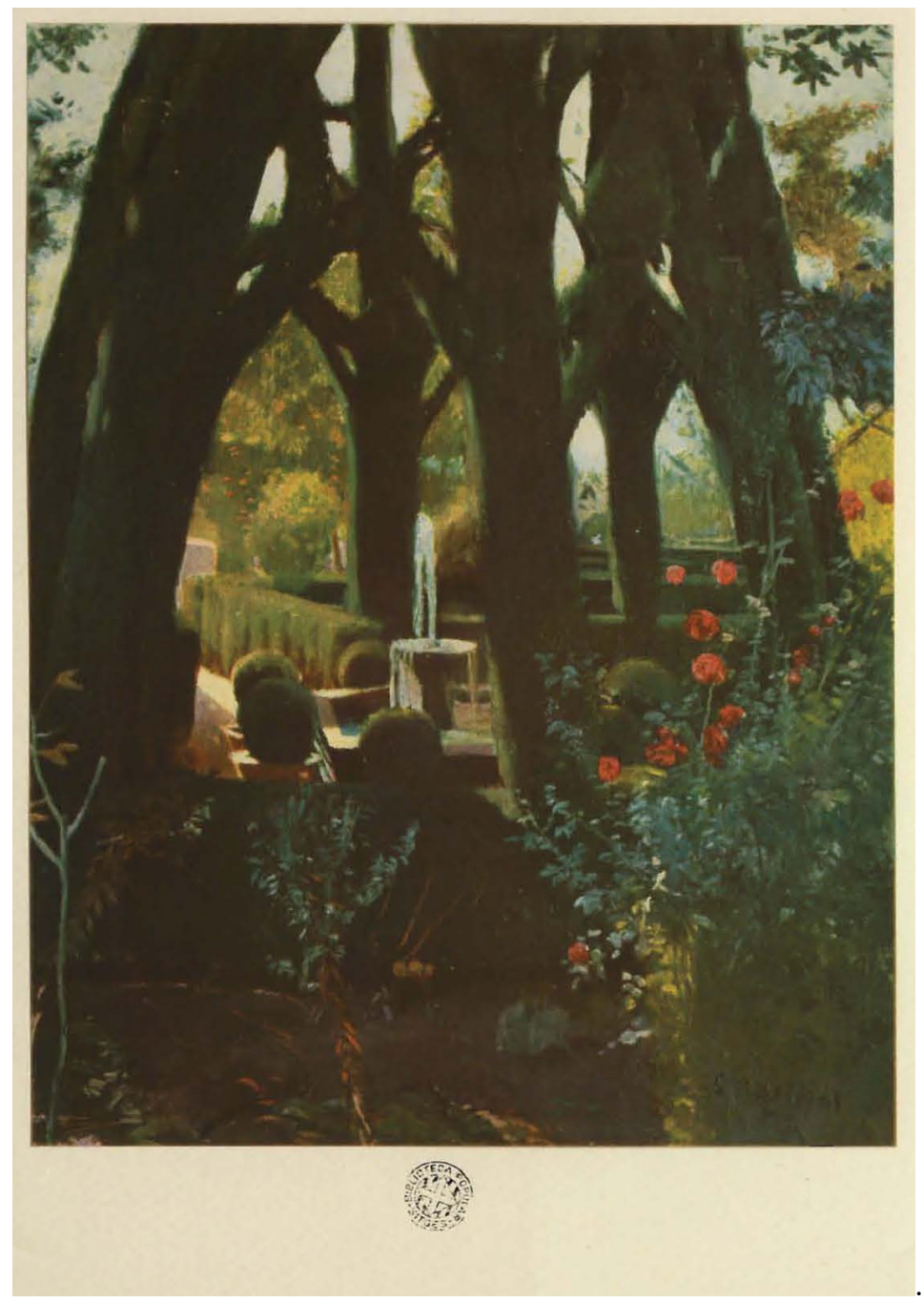

La fuente de la Odalisca 
Sigue Darío con su preferencia por caminos trazados en los parterres, como en el primer grabado, y regresa ahora a una zona de Mallorca, Alfàbia, entre la capital y Soller, que conoce bien. Destaca en este libro la coloración naranja del grabado de Rusiñol, con su curiosa arquitectura basada en una columnata cubierta por un techo de cristal:

Y en la Isla Dorada otra vez, el «Caminal d'Alfàbia», asimismo de cuento de Oriente, con sus columnas y sus cristales armoniosos, y las flores siempre. (Ibídem)

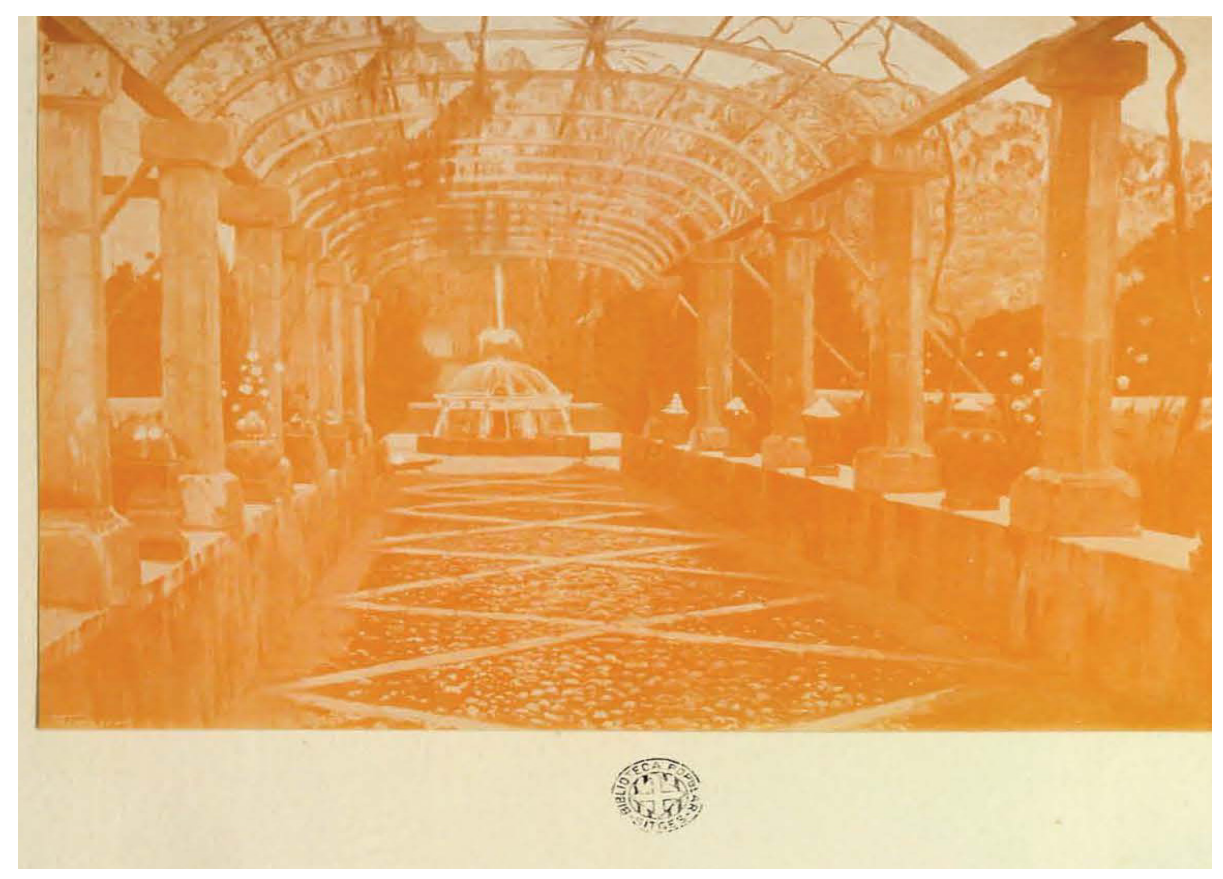

Caminal d'Alfäbia

La siguiente nota de Darío es sobre la Glorieta de los enamorados del Generalife, una imagen de la que siempre recordaremos el comentario de Enrique Díez Canedo en $1907^{8}$-el mismo año de la nota de Darío-, cuando centraba en ésta (y alguna otra más) la profunda originalidad del pintor catalán y decía que sus jardines sólo eran similares en la tradición española a los dos paisajes de la Villa Médicis que pintó Velázquez, "semejantes en la inspiración, pero no en el sentimiento" porque el pintor sevillano tiene una "serenidad material, horaciana", mientras Rusiñol es "crepuscular y elegíaco", aunque en los dos se construye "el

8 Díez Canedo lo público en 1907 el número 6, año I, págs. 224-229 de la revista Renacimiento, dirigida por Gregorio Martínez Sierra, en un monográfico dedicado al pintor y escritor catalán en el que, junto a él, colaboran André Gonzalez Blanco, José Francés, Joan Maragall, Francisco Navarro y Ledesma, Jean Lorrain, Gregorio Martínez Sierra, Francisco Acebal, Enrique Gómez Carrillo y Miguel S.Oliver,. Hay edición facsímil en Sevilla, Renacimiento, 2002. Prólogo de Luis García Montero. 
paisaje por el paisaje". Recordaba Díez Canedo que Rusiñol decía que "los jardines son el paisaje puesto en verso", frente a la otra naturaleza. Darío es escueto en su comentario, anecdótico aquí al principio, para concluir en el arcaísmo de la composición y en el agua que humedece el tiempo:

De nuevo es en la tierra granadina, la «Glorieta de los Enamorados», cuyo nombre recuerda lo que una dama sabidora dejó escrito en el álbum del Generalife, que era bueno «para amar». Aquí para amar es bueno este asilo de verdores, de una composición arcaica, y en donde un aislado chorro de agua apenas humedece el paso de las horas. (Ibidem)

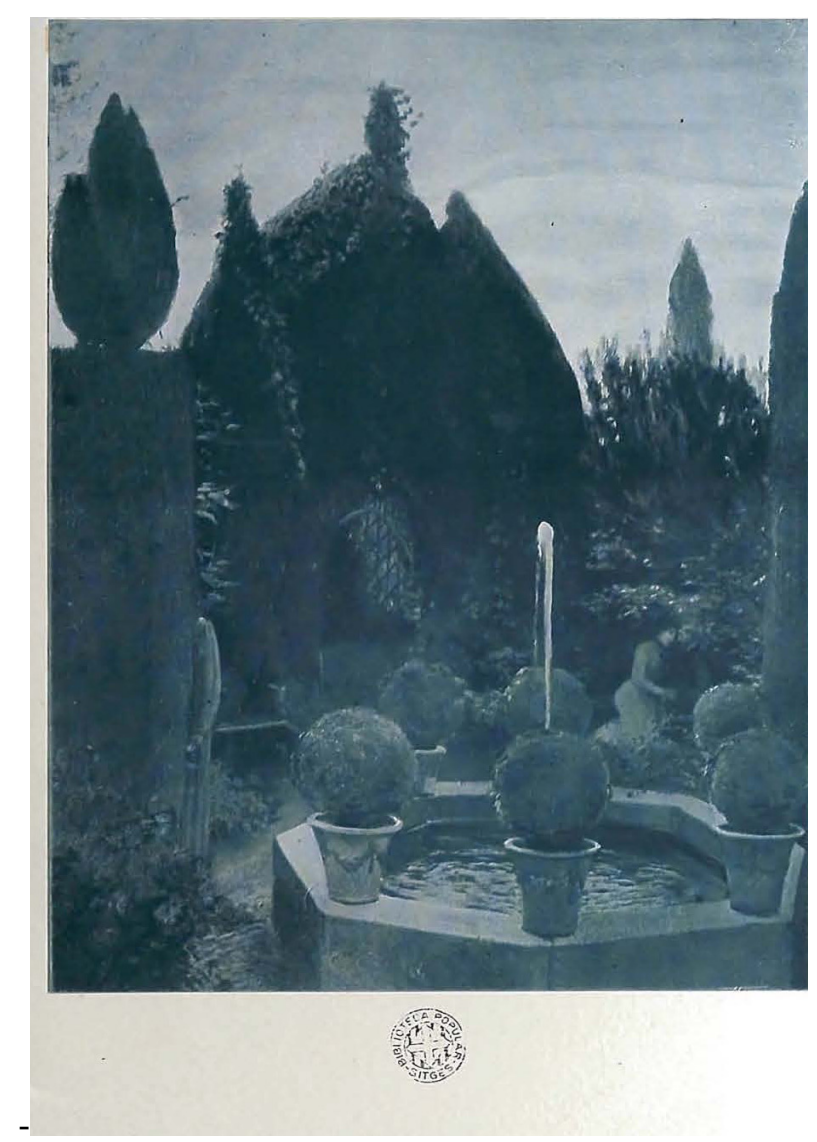

Glorieta de los enamorados

Siguen descripciones sin identificación concreta que remiten a varios grabados. La música se aúna finalmente a las sensaciones descritas, y los mitos construyen las nuevas sendas que la perspectiva de Rusiñol ha trazado como "páginas poemales": 
He aquí, también en Granada, una sucesión de arcos espléndida, o la «villa» triste ante los recortados cipreses. Y en Aranjuez, la senda de rosas hacia la enorme herradura del espeso arco... Y otras páginas poemales, en que la luna influye con su hechizo; o en que ordenadas graderías ascienden hacia unos como oscuros santuarios de profanos cultos. Aguas, follajes, tiestos, en la ornamentación de las gráficas músicas, gráficas músicas que bien habrían violado las violas que acariciaron en días líricos los oídos de la imperecedera Gioconda. En estos jardines ya es la clara voz de primavera, ya el canto autumnal el que se escucha. (Ibídem).

\section{Para la creación de paisajes}

Hay dos textos que siempre he vinculado mentalmente en la apreciación del buscador de cuadros a través de paisajes y que se sentaba luego en su mesa de poeta o de periodista: el del final del "Álbum porteño" de $A z u l$ cuando Ricardo, "el poeta lírico incorregible", tras recorrer el Cerro Alegre, construir visualmente una acuarela, un paisaje y un aguafuerte, desciende a su casa y

aquel soñador se encontraba en su mesa de trabajo, donde las cuartillas inmaculadas estaban esperando las silvas y los sonetos de costumbre, a las mujeres de los ojos ardientes. ¡Qué silvas! ¡Qué sonetos! La cabeza del poeta lírico era una orgía de colores y de sonidos. Resonaban en las concavidades de aquel cerebro martilleos de cíclopes, himnos al son de tímpanos sonoros, fanfarrias bárbaras, risas cristalinas, gorjeos de pájaros, batir de alas y estallar de besos, todo como en ritmos locos y revueltos. Y los colores agrupados, estaban como pétalos de capullos distintos confundidos en una bandeja, o como la endiablada mezcla de tintas que llena la paleta de un pintor... (Darío, 2011: 278)

Materialmente es un conjunto de sinestesias las que pueblan y casi estallan en el cerebro, en una actitud de confusión entre colores y sonidos que el propio Darío atribuye a sí mismo en un momento excepcional de Peregrinaciones, el libro de su viaje europeo en 1900, en el que tras la visión de pinturas en el "Gran Palacio" de París (Bonnat, Collin, Constand, Carrière...), nos dice que se refugia en la creación porque, tras los colores y las formas que le rodean, "mil nebulosas de poemas flotan" en su interior, aunque prevalece finalmente la obligatoriedad de un apunte, una impresión, una idea que le exige la obligación de periodista:

Rodeado de un mar de colores y de formas, mi espíritu no encuentra ciertamente en dónde poner atención con fijeza. Sucede que, cuando un cuadro os llama por una razón directa, otro y cien más os gritan las potencias de sus pinceladas o la melodía de sus tintas y matices. $\mathrm{Y}$ en tal caso pensáis en la realización de muchos libros, en la meditación de muchas páginas. Mil nebulosas de poemas flotan en el firmamento oculto de vuestro cerebro; mil gérmenes se despiertan en vuestra voluntad y en vuestra ansia artística; pero el útil del trabajador, vuestro oficio, vuestra obligación para con el público del periódico, os llaman a la realidad. Así apuntáis, informáis, vais de un punto a otro, cogéis aquí una 
impresión como quien corta una flor, allá una idea, como quien encuentra una perla; y a pocos, a pasos contados, hacéis vuestra tarea, cumplís con el deber de hoy, para recomenzar al sol siguiente, en la labor danaideana de quien ayuda a llenar el ánfora sin fondo de un diario. (Darío, 1918: 39)

Las descripciones que construyen paisajes se sistematizan en esta obra en la que las proximidades de Pisa por ejemplo adquieren matices pictóricos como en la siguiente perspectiva que se traza mediante una conjunción de sentidos que da cuenta de colores y sonidos:

Es la hora del comienzo de la tarde y el sol hace brillar como polvo de plata el camino trillado. Los montes pisanos marcan su relieve gris sobre el azulado fondo del cielo, y en su cima, la Verruca, sobre su asiento de rocas desgreñadas, calca su silueta de castillo de cuento. Voy en la llamarada del sol y en el vaho ardiente del suelo. Un exceso de vida se desborda de los campos circundantes, y sigo mi camino entre verdores de hojas, al estridente aserrar de las cigarras. El verde de las viñas a un lado, y las uvas negras manchan, colgadas de las guirnaldas, las ramas hojosas; el verde de los olivos al otro, y las hojas semejan manojos de las minas argentadas y hacen un manso ruido al roce del viento. ¿Cuánto tiempo hacía que no escuchaba el bullicio de las cigarras? Era desde los años que viviera en el caliente trópico, donde los mangos sonoros se debaten al soplo de aires furiosos, y el sol violento y calcinante hace humear los pantanos y gritar los bosques (Darío, 1917: 135-6)

En Tierras solares, en 1904, Darío realiza una amplia propuesta descriptiva diferenciada entre las maturalezas luminosas (las de España -Andalucía y Barcelona-, más el Norte de África y, por decisión del editor, Venecia y Florencia) y las tierras de brumas (las del Rhin, Hamburgo, Berlín, Francfort, Viena, Budapest...).

En esta obra aparece un nuevo recuerdo del pintor catalán:

Rusiñol, espíritu encantador, pintor de soñaciones, maestro de melancolías, y el cual en todas sus obras pone algo de la tristeza que ha aprendido en las partes dolorosas y misteriosas de la vida. Le conocí en París, después de ser muy amigos desde lejos. Es la primera vez en que la persona no me causó decepción por el artista. Personal e intelectualmente es el mismo. Gracias a Dios que no me ha quitado aún ¡Ni me lo quite nunca! - el don de admirar. Admirar de veras, con mente sincera, con el corazón o con la cabeza, o con ambas cosas. (Darío, 1917c: 15)

Para redactar estas notas sobre Darío y Rusiñol, he vuelto a leer otra vez textos del poeta nicaragüense, como Páginas de arte (1920), que indican que estamos ante una de las reflexiones más continuas y sugerente sobre los pintores contemporáneos, franceses y españoles. Quizá en el futuro será necesario, en la línea de los trabajos previos personales que he mencionado, poner las imágenes y las reflexiones juntas en un lugar que de cuenta de la intensa reflexión que realizó Darío sobre casi un centenar de pintores y de cuadros concretos que comentó 
detalladamente, en la búsqueda del poema-pintura, con la inteligencia sensible que siempre desplegaba. Y será necesario entonces volver a pensar sobre ello.

\section{Referencias bibliográficas}

Acereda, Alberto, "Dos visones del espacio marino como modernidad. Entre la poesía de Rubén Darío y la pintura de Joaquín Sorolla”, Revista de Literatura, LXV (2003), 129, pp. 119-143.

Balcells, José María, “Jardines abandonados en Juan Ramón Jiménez y en Santiago Rusiñol”, Caligrama, no. 3 (1991), pp. 35-58.

Darío, Rubén. España contemporánea, en Obras Completas, vol. XIX. Madrid: Ed. Mundo Latino, 1917.

- Parisiana en Obras Completas, vol. V. Madrid: Ed. Mundo Latin, 1917b.

- Tierras solares en Obras Completas, vol. III. Madrid: Ed. Mundo Latino, 1917c.

-Peregrinaciones en Obras Completas, vol. XII. Madrid: Ed. Mundo Latino, 1918.

-Páginas de arte en Obras Completas, vol. IV. Madrid: Ed. Renacimiento, 1920 (circa, s.a.?).

-Obras Completas. Madrid: Afrodisio Aguado, vol. I, 1950.

- La isla de oro. El oro de Mallorca, ed. de Luis Maristany. Barcelona: JRS Editor, 1978.

- Cantos de vida y esperanza. Los cisnes y otros poemas. Ed. de José Carlos Rovira. Madrid: Alianza Editorial, 2004.

- Obra poética completa. Ed. de José Carlos Rovira con la colaboración de Sergio Galindo. Madrid: Biblioteca Castro, 2011.

Díez Canedo, Enrique, "Santiago Rusiñol: la pintura", Renacimiento, no. 6, año I (1907), pp. 224-229. Hay edición facsímil en Sevilla: Renacimiento, 2002. Pról. de Luis García Montero.

Litvak, Lily, "La dama ante el espejo. Darío y Watteau", Imágenes y textos. Estudios sobre literatura y pintura 1849-1936. Amsterdam: Rodopi, 1988, pp. 51-66.

- "Ut pintura poesis. La descripción de la obra de arte en Rubén Darío", en Cristóbal Cuevas (ed.), Rubén Dario y el arte de la prosa. Ensayo, retratos y alegorías. Málaga: Publicaciones le literatura española contemporánea, 1988b, pp. 133-154.

Martínez Rivas, Carlos, "Watteau y su siglo en Rubén Darío", Cuadernos Hispanoamericanos, 212-213 (1967), pp. 445-452.

Martí Monterede, Antoni, "Rubén Darío y Santiago Rusiñol: politica i periodisme literari en la Barcelona modernista", Catalan Review, no. XXX (2016), pp. 275-304.

Montojo, Fabián, "Rubén Darío. La isla de oro. Jardines de España", en su Web En alta mar (http://fabian.balearweb.net/post/116200) [consultado en 16 de marzo de 2016].

Rovira, José Carlos, "Sobre el tiempo chileno, las ciudades, la cultura francesa y Pedro Balmaceda", Ínsula, no. 838, octubre de 2016a, pp. 22-25.

—“Rubén Darío: geografía, pintura y paisajes", Centroamericana, nº 26.2. (2016b), pp.131-158.

Rusiñol, Santiago. Jardins d'Espanya. Barcelona: Ed. Can Thomas, 1903.

Schulman, Ivan. A., "Rubén Darío: pintor", en Rubén Darío en su laberinto. Ed. de Rocío Oviedo. Madrid: Verbum, 2014, pp. 23-32. 